ISSN 1979-5572 (print)

ISSN 2541-6480 (online

http://ejurnal.iainpare.ac.id/index.php/kuriositas

\title{
KURIOSITAS
}

Media Komunikasi Sosial dan Keagamaan

\begin{tabular}{lll}
\hline Volume 11 & No. 2, Desember 2018 & Halaman 189-210 \\
\hline
\end{tabular}

\section{INOVASI PEMBELAJARAN GURU PENDIDIKAN AGAMA ISLAM BERBASIS TEKNOLOGI INFORMASI}

\author{
Tanwir' ${ }^{1}$, Hamdanah Said ${ }^{2}$ \\ ${ }^{12}$ Institut Agama Islam Negeri Parepare \\ tanwiruamar60@gmail.com
}

\begin{abstract}
The study was aimed to: 1) describing the Islamic Education teachers' performance on SMA in Parepare City; 2). describing the Senior Hight School Students' learning outcomes in Parepare City; 3). Determining whether or not there was an influence of Islamic Education teachers' performance on the Senioe Hight Schools students' learning outcomes in Parepare City. The result of the study revealed that: 1) the Islamic Education teachers' performance of Senior Hight Schools in Parepare City was in good category; 2) the students' learning outcomes of Islamic Education tended to be in good category, 3) there was a significant influence of Islamic Education teachers' performance on the Senior High Schools students' learning outcomes in Parepare City. The study had implication: 1) the Islamic Education teachers realized the importance of a teacher working professionally, having high performance both in learning plan, learning implementation and evaluating the students' learning outcomes, which can lead to the hight achievement of learning outcomes as well, 2) there was a concrete evidence of the implementation of education and learning practices in Senior High Schools which was necessary to be constantly improved.
\end{abstract}

Keywords: Teachers' Performance, Learning Outcomes, Islamic Education

\begin{abstract}
ABSTRAK
Penelitian ini bertujuan untuk: 1) mendeskripsikan kinerja guru PAI SMA di Kota Parepare; 2) Mendeskripsikan hasil belajar peserta didik SMA di Kota Parepare; dan 3) Mengetahui pengaruh kinerja guru PAI terhadap hasil belajar peserta didik SMA di Kota Parepare. Penelitian ini menggunakan pendekatan kuantitatif dan merupakan jenis penelitian survey dengan dua variabel yaitu
\end{abstract}


kinerja guru PAI sebagai variabel independen $(X)$, dan hasil belajar peserta didik sebagai variabel dependen (Y). Hasil penelitian menunjukkan: 1) kinerja guru PAI SMA di Kota Parepare berada pada kategori baik, 2) hasil belajar PAI peserta didik cenderung berada pada kategori baik, 3) terdapat pengaruh yang signifikan kinerja guru PAI terhadap hasil belajar peserta didik SMA di Kota Parepare. Penelitian ini memberikan implikasi yaitu: 1) Guru PAI kembali menyadari bahwa betapa pentingnya seorang guru bekerja secara profesional, memiliki kinerja yang tinggi, baik dalam perencanaan pembelajaran, pelaksanaan pembelajaran maupun dalam hal evaluasi dan penilaian hasil belajar peserta didik, yang dapat mengantarkan tercapainya hasil belajar yang tinggi pula. 2) Adanya bukti konkrit dari praktik pelaksanaan pendidikan dan pembelajaran di SMA yang perlu senantiasa ditingkatkan.

Kata Kunci: Kinerja Guru PAI, Hasil Belajar, SMA Kota Parepare.

\section{PENDAHULUAN}

Setiap kemajuan yang diraih manusia selalu melibatkan kreativitas.(Munandar, 2000) Demikian pula halnya dengan kemajuan yang diraih seorang guru tidak terlepas dari kemampuan guru mengoptimalkan kreativitasnya. Kreativitas serta aktivitas guru harus mampu menjadi inspirasi bagi para peserta didik. Sehingga peserta didik akan lebih terpacu motivasinya untuk belajar, berkarya dan berkreasi. Guru berperan aktif dalam pengambangan kreativitas siswa, yaitu dengan memiliki karakteristik pribadi guru yang meliputi motivasi, kepercayaan diri, rasa humor, kesabaran, minat dan keluwesan (fleksibel). Guru yang kreatif mempunyai semangat dan motivasi tinggi sehingga bisa menjadi motivator bagi peserta didiknya untuk meningkatkan dan mengembangkan kreativitasnya, khususnya yang tertuang dalam sebuah bentuk pembelajaran yang inovatif. Artinya selain menjadi seorang pendidik, guru juga harus menjadi seorang kreator yang mampu menciptakan kondisi belajar yang nyaman dan kondusif bagi peserta didik dalam rangka mewujudkan hasil belajar peserta didik yang maksimal.

Dapat dipahami bahwa, kedudukan guru menjadi titik sentral dan awal dari semua pembangunan pendidikan, karena itu tanpa guru, maka dunia pendidikan tidak memiliki arti yang signifikan. Posisi guru dalam pelaksanaan pendidikan berada pada garda terdepan, keberadaan dan kesiapannya menjalankan tugas sebagai pendidik, sangat menentukan bagi terselenggaranya suatu proses pendidikan.

Guru sebagai salah satu unsur utama dalam pendidikan, kelihatannya memiliki segi-segi tertentu yang menarik untuk dikaji, sebab memungkinkan dapat diperoleh seperangkat pengetahuan yang bersifat teoritis tentang guru, 
khususnya mengenai hal-hal yang berkaitan dengan tugas pokok sebagai pendidik. Sebenarnya tidak hanya bermanfaat secara internal terhadap guru itu sendiri, tetapi juga dipahami dapat berguna secara eksternal terhadap mereka yang hidup dan bekerja selain guru, termasuk pihak pengelola lembaga-lembaga pendidikan yang telah dan akan merekrut atau mengangkat guru sebagai tenaga pendidik.

Melalui kemampuan kinerja guru PAI diharapkan dapat menyusun program pembelajaran yang efektif, menciptakan iklim kelas yang kondusif dan membangun unjuk peserta didik serta dapat mengarahkan peserta didik pada peningkatan hasil belajarnya. Di sekolah, guru PAI senantiasa berinteraksi dengan guru lainnya, memonitor dan menilai kegiatan peserta didik sehari-hari. Rendahnya kinerja guru PAI akan berpengaruh terhadap pelaksanaan tugasnya sebagai pendidik yang pada gilirannya akan berpengaruh pula terhadap pencapaian tujuan pendidikan. Rendahnya kinerja guru PAI harus diidentifikasi penyebabnya. Ada berbagai faktor yang mempengaruhi terhadap kinerja seorang guru yang memerlukan penelitian lebih lanjut.

Akhir-akhir ini ada gejala kecenderungan melemahnya kinerja guru. Guru melaksanakan tugasnya hanya sekedarnya saja tanpa ada persiapan materi maupun metode pembelajaran yang akan digunakan, guru tidak menguasai materi dengan kuat sehingga pembelajaran jadi monoton yang penting cepat selesai maka tentunya berpengaruh kepada siswanya. (Sumadi, 2012) Bahkan ada kesan sebagian guru lebih sekedar memenuhi persyaratan administrasi untuk layak mendapatkan tunjangan sertifikasi. Realitas ini menjadi sebab amat urgennya untuk mengkaji mengapa kondisi seperti yang dikemukakan tersebut dapat terjadi. Apakah ada unsur subyektivitas di dalamnya.

Proses pembelajaran akan berlangsung dengan baik, apabila didukung oleh guru yang mempunyai kompetensi dan kinerja yang tinggi, termasuk guru PAI. Berdasarkan observasi awal penulis di lapangan ditemukan fenomena pada SMA di Kota Parepare yang menunjukkan gejala bahwa kinerja guru Pendidikan Agama Islam dalam melaksanakan tugasnya belum sesuai dengan harapan ideal masyarakat yakni menjadikan alumninya tidak hanya cerdas intelektual tetapi juga cerdas emosional dan spiritual. Dalam pada itu, pelaksanaan tugas utama guru PAI sebagaimana yang diamanahkan dalam Undang-Undang RI nomor 20 Tahun 2003 tentang Sistem Pendidikan Nasional yakni mengajar, mendidik, membimbing, mengarahkan, melatih, menilai, dan mengevaluasi peserta didik dalam bidang PAI tampaknya juga belum sepenuhnya dijalankan dengan baik oleh para guru PAI. Selain itu juga masih tampak adanya guru PAI yang memiliki keterbatasan kemampuan dalam menggunakan multimedia pembelajaran. Bahkan di antara mereka ada yang tidak berada di Sekolah pada 
jam efektif pembelajaran. Kondisi guru PAI seperti itulah yang menjadi permasalahan di lembaga pendidikan formal. Dengan adanya guru yang mempunyai kinerja rendah, sekolah, khususnya SMA di Kota Parepare akan sulit untuk mencapai hasil sebagaimana yang diharapkan, yakni pendidikan dan pembelajaran yang berkualitas tinggi.

Lebih lanjut untuk melihat bagaimana kinerja guru PAI, dan pengaruhnya terhadap peningkatan kualitas PAI, maka perlu penelitian lebih lanjut di lapangan. Untuk tujuan tersebut, maka diperlukan lokasi penelitian, dan berdasarkan hasil observasi awal, maka dipilih SMA di Kota Parepare, sebab realitas menunjukkan bahwa mata pelajaran PAI yang diajarkan pada SMA di Kota Parepare telah dan sementara berusaha mengembangkan ilmu pengetahuan, meningkatkan iman dan taqwa peserta didik, meningkatkan kinerja guru untuk menjadikan lembaga pendidikan yang berkulitas.( Dinas Pendidikan Nasional Kota Parepare, 2012) Berhasil tidaknya pencapaian prestasi hasil belajar peserta didik dalam mata pelajaran PAISMA di Kota Parepare, terkait kinerja guru yang memerlukan penelitian secara akurat di lapangan.

\section{METODE}

Sesuai dengan sifat permasalahan dan objek yang dikaji maka jenis penelitian ini adalah penelitian survey. Kerlinger sebagaimana yang dikutip Sugiyono mengemukakan bahwa penelitan survey adalah "penelitan yang dilakukan pada populasi besar maupun kecil, tetapi data yang dipelajari adalah data dari sampel yang diambil dari populasi tersebut". (Sugiyono, 2007) Dengan demikian penelitian ini sejenis penelitian survei, yang mengambil sampel dari suatu populasi dan menggunakan kuesioner sebagai alat pengumpul data yang pokok.(Masri Singarimbun dan Sofyan Efendi, 2000) Jika dilihat dari jenis data maka penelitian ini merupakan penelitian kuantitatif korelasional yang memusatkan pada dua jenis variabel yakni variabel independen (bebas) dan variabel dependen (terikat).

Penelitian ini dilaksanakan di Kota Parepare yakni pada lima lokasi, yaitu SMA Negeri 1 Parepare, SMA Negeri 3 Parepare, SMA Negeri 5 Parepare, SMA Muhammadiyah, dan SMA Hidayatullah Parepare.

Terdapat dua jenis variabel dalam penelitian ini yakni variabel independen $(\mathrm{X})$ dan variabel dependen $(\mathrm{Y})$. Variabel independen dalam penelitian ini adalah kinerja guru PAI $(X)$ dan variabel dependen yaitu hasil belajar PAI (Y). Dengan demikian maka bentuk korelasi variabel dalam penelitian ini adalah korelasi sederhana atau korelasi bivariat.

Penelitian ini merupakan penelitian kuantitatif korelasional dengan menggunakan paradigma sederhana. Paradigma sederhana terdiri atas satu 
variabel independen yakni kinerja guru dan satu variabel dependen yakni hasil belajar peserta didik.

\section{PEMBAHASAN}

Deskripsi data yang berkaitan dengan variabel yang diteliti yakni variabel bebas (independent variable) yaitu "Kinerja Guru PAI" dan variabel terikat (dependent variable) yaitu "hasil belajar", disajikan dengan menggunakan analisis statistik deskriptif dan inferensial. Analisis statistik deskriptip digunakan untuk menjawab rumusan masalah pertama dan kedua, sedangkan analisis inferensial digunakan untuk menjawab rumusan masalah ketiga dan menguji hipotesis yang telah diajukan sebelumnya, apakah diterima atau ditolak.

Deskripsi data yang diperoleh dari lapangan dimaksudkan untuk mengetahui gambaran secara umum mengenai variabel yang diteliti. Pada bagian ini disajikan data hasil penelitian meliputi: deskripsi data setiap variabel penelitian meliputi: tendensi sentral yakni skor rata-rata (mean), skor rata dua data tengah (median), skor yang memiliki frekuensi terbanyak (modus), ukuran tendensi penyebaran simpangan baku (standard deviation), distribusi frekuensi, dan diagram histogram. Di samping itu dikemukakan pula hasil uji persyaratan analisis, pengujian hipotesis, pembahasan hasil penelitian dan keterbatasan penelian.

\section{Temuan data}

\section{Kinerja Guru Pendidikan Agama Islam SMA di Kota Parepare}

Sebelum mengumpulkan data tentang kinerja guru PAI SMA di Kota Parepare, terlebih dahulu dilakukan prasyarat yaitu uji validitas dan uji reliabilitas instrumen penelitian. Uji validitas dilakukan untuk menentukan validitas butir-bitir pernyataan yang terdapat pada instrumen penelitian. Sedangkan uji reliabilitas dilakukan untuk memastikan konsistensi butir-butir instrumen penelitian yang digunakan.

\section{Uji Validitas Instrumen}

Uji validitas instrumen dilakukan untuk mengetahui tingkat kevalidan atau kesahihan instrumen penelitian. Suatu instrumen dinyatakan valid apabila mampu mengukur apa yang diinginkan.

Ujicoba instrumen penelitian dilakukan di SMA Negeri 4 Kota Parepare. Berikut ini dikemukakan hasil ujicoba instrumen penelitian yang telah diberikan kepada 60 responden yang memiliki ciri sama dengan subjek penelitian. Ringkasan hasil ujicoba dapat dilihat pada lampiran 2.

Berdasar pada hasil ujicoba instrumen maka terdapat 3 butir angket yang tidak digunakann atau di drop sebab tidak valid yaitu nomor 1, 2, dan 9 sebab 
nilai $\mathrm{r}$ hitungnya kurang dari 0,3 , sehingga jumlah item pernyataan angket yang digunakan berjumlah 43 item.

\section{Uji Reliabilitas Instrumen}

Suatu alat ukur dikatakan baik apabila alat ukur tersebut mempunyai tingkat reliabilitas atau keandalan yang tinggi, sehingga tingkat reliabilitas suatu alat ukur harus diuji. Rumus yang digunakan untuk menguji reliabilitas instrumen variabel penelitian ini yaitu rumus teknik Cronbach's Alpha.

Hasil ujicoba menunjukkan nilai reliabilitas atau konsistensi instrument adalah 0,929. Ini menunjukkan bahwa reliabilitas instrument untuk kinerja guru PAI pada pelaksanaan pembelajaran sangat tinggi.

Data penelitian menyangkut variabel Kinerja Guru PAI SMA di Kota Parepare $(X)$ berupa kumpulan skor hasil yang diperoleh melalui kuesioner, yang direspon oleh peserta didik (responden) berdasarkan persepsi mereka yang menjadi unit analisis penelitian. Variabel kinerja guru PAI diukur dengan menggunakan instrumen yang terdiri atas 43 item pernyataan. Skor terendah untuk setiap pernyataan positif adalah 1 dan skor tertinggi adalah 5 sehingga skor teoritiknya antara 43-215. Berdasarkan data hasil penelitian, diketahui rentang skor variabel kinerja guru PAI SMA di Kota Parepare adalah antara 116 sampai 200. Adapun rentang skor variabel kinerja guru PAI Sebesar 84 menunjukkan rentang skor variabel tersebut sangat beragam dan bertingkat.

Tabel 1. Rangkuman Hasil Analisis Deskripsi Kinerja Guru PAI SMA di Kota Parepare Statistics

Kinerja Guru PAI

\begin{tabular}{|c|c|c|}
\hline \multirow{2}{*}{$\mathrm{N}$} & Valid & 236 \\
\hline & Missing & 0 \\
\hline Me & & 169,70 \\
\hline Me & & 169,00 \\
\hline Mo & & $165^{a}$ \\
\hline Std. & & 14,345 \\
\hline Vari & & 205,775 \\
\hline Ran & & 67 \\
\hline Min & & 135 \\
\hline Mas & & 202 \\
\hline Sum & & 40050 \\
\hline
\end{tabular}

a. Multiple modes exist. The smallest value is shown

Merujuk pada tabel 1, maka diketahui harga rata-rata total skor dari 236 responden sebesar 169.70. Selanjutnya, hasil perolehan data menunjukkan 
ukuran tendensi sentral yang lain yakni median sebesar 169,00, mode sebesar 165, standar deviasi sebesar 14.345 dan varians sebesar 205,775. Sedangkan distribusi frekuensi kinerja guru PAI dapat dilihat pada table berikut ini.

Tabel 2. Ditribusi Frekuensi Kinerja Guru Pendidikan Agama Islam SMA di Kota

Parepare

\begin{tabular}{|c|c|c|}
\hline $\begin{array}{c}\text { Kelas } \\
\text { Interval }\end{array}$ & \multicolumn{1}{|c|}{ Frekue } & Persenta \\
\hline $135-143$ & 7 & nsi (fi) \\
\hline $144-152$ & 23 & 9.97 \\
\hline $153-161$ & 35 & 14.83 \\
\hline $162-170$ & 58 & 24.58 \\
\hline $171-179$ & 50 & 21.19 \\
\hline $180-188$ & 39 & 16.52 \\
\hline $189-197$ & 19 & 8.05 \\
\hline $198-206$ & 5 & 2.11 \\
\hline Jumlah & $\mathbf{2 3 ~ 6}$ & $\mathbf{1 0 0 . 0 0}$ \\
\hline
\end{tabular}

Jumlah kelas interval pada tabel 4 ditentukan dengan menggunakan rumus Sturges yakni 1+ (3,3 log $n)$ sehingga diperoleh hasil perhitungan 8.83, sehingga ditetapkan jumlah kelas sebanyak 8 kelas dengan panjang kelas $=8$. Frekuensi skor terbanyak pada tabel 4 berada pada kelas interval 162-170 dengan frekuensi 58 atau setara dengan $24.58 \%$. Data yang terlihat pada tabel distribusi frekuensi jika dibandingkan dengan harga rata-rata yakni 169,70 menunjukkan bahwa skor kinerja guru PAI SMA di Kota Parepare yang berada di bawah kelompok rata-rata sebanyak 65 responden atau setara dengan $27.54 \%$, yang berada pada kelompok skor rata-rata adalah sebanyak 58 responden atau setara dengan $24.58 \%$, dan yang berada pada kelompok skor di atas harga rata-rata sebanyak 113 responden, atau setara dengan 47.88\%. Hal ini menunjukkan bahwa kecenderungan perolehan skor kinerja Guru PAI SMA di Kota Parepare (variable X) dapat dikategorikan baik.

Selanjutnya, disajikan pula data distribusi frekuensi kinerja guru dalam bentuk grafik histogram sebagai berikut:

Gambar 1. Histogram Frekuensi Kinerja Guru PAI SMA di Kota Parepare 


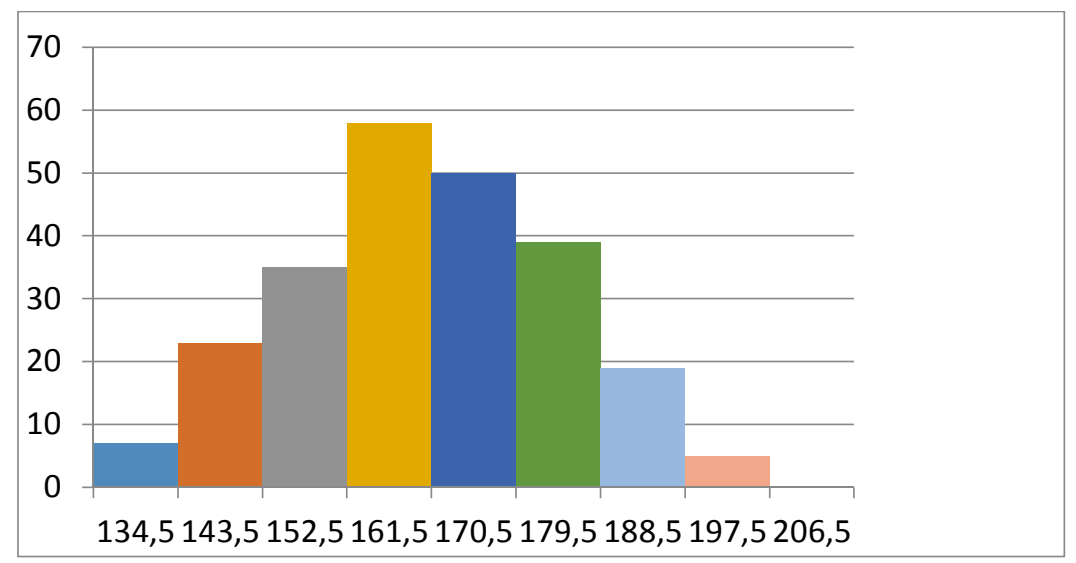

Data pada histogram di atas menggambarkan bahwa guru PAI SMA di Kota Parepare telah memiliki kinerja yang baik sebab modus berada pada kelas interval rata-rata dan frekuensi skor yang berada pada kelas interval di atas harga rata-rata lebih banyak dibanding dengan frekuensi skor di bawah harga rata-rata . Hal ini sesuai pula dengan hasil penelusuran dokumen di lapangan yang menunjukkan adanya kinerja guru PAI SMA di Kota Parepare berada pada kategori baik.

Selanjutnya, kategori kinerja guru PAI dilihat pula dengan membagi skor perolehan dengan skor kriterium. Skor total variabel kinerja guru PAI yang diperoleh dari hasil penelitian adalah 40.050. Jumlah item kuesioner yang dinyatakan valid sebanyak 43 item, dan setiap item mempunyai 5 (lima) alternatif pilihan sehingga skor teoretik tertinggi variabel ini setiap responden adalah 43 × $5=215$, karena jumlah responden 236 orang maka skor kriterium variabel kinerja guru adalah 215 × $236=50.740$. Dengan demikian tingkat kinerja guru PAI adalah 40.050 : $50.740=0,7893$ atau $78,93 \%$ dari kriterium yang ditetapkan, sehingga dapat ditarik kesimpulan bahwa tingkat kinerja guru PAI SMA di Kota Parepare termasuk kategori sedang atau baik.

Berdasarkan uraian di atas dapat diketahui bahwa kinerja guru PAI termasuk kategori baik. hal ini sesuai pula dengan hasil penelusuran dokumen di lapangan yang menunjukkan adanya kinerja guru PAI SMA di Kota Parepare cenderung baik, khususnya dalam perencanaan pembelajaran, pelaksanaan proses pembelajaran maupun dalam penilaian hasil belajar peserta didik.

Temuan dalam penelitian ini didasarkan pada persepsi peserta didik tentang kinerja guru PAI SMA di Kota Parepare yang hampir sama dengan hasil PKG yang dilakukan oleh pengawas PAI. Apabila temuan ini dibandingkan dengan hasil penelusuran dokumen yang berkenaan dengan penilaian kinerja guru yang dilakukan oleh pengawas PAI yang telah disahkan oleh kepala SMA maka hasil PKG yang terdokumentasi tersebut lebih besar yakni 83,23 dibanding persepsi responden yakni 78,93 (selisih 4,3). Namun demikian kedua skor tersebut barada pada kategori baik. Penentuan kategori ini didasarkan pada 
pendapat H. E. Mulyasa sebagaimana telah dikemukakan pada Bab III terdahulu. Rekapitulasi penilaian kinerja guru PAI berdasarkan penilaian pengawas PAI dapat dilihat pada bagian lampiran.

\section{Hasil Belajar Pendidikan Agama Islam Peserta Didik SMA di Kota Parepare}

Data penelitian menyangkut variabel hasil belajar PAI (Y) berupa kumpulan skor hasil belajar yang diperoleh peserta didik (responden) berdasarkan nilai rapor sebagai hasil penilaian yang telah dilaksanakan oleh guru PAI yang menjadi unit analisis penelitian. Berdasarkan data hasil penelitian, diketahui rentang skor hasil belajar PAI peserta didik SMA di Kota Parepare adalah antara 70 sampai 98. Adapun rentang skor variabel hasil belajar PAI peserta didik sebesar 28, ini menunjukkan rentang skor variabel yang beragam dan bertingkat. Lebih jelasnya dapat dilihat pada tabel berikut ini.

Tabel 3. Rangkuman Hasil Analisis Deskriptif Hasil Belajar PAI Peserta Didik Statistics

Hasil Belajar PAI

\begin{tabular}{|l|l|}
\hline N $\quad$ Valid & 236 \\
\multicolumn{1}{|c|}{ Missing } & 0 \\
Mean & 87,72 \\
Median & 90,00 \\
Mode & 90 \\
Std. Deviation & 4,818 \\
Variance & 23,213 \\
Range & 28 \\
Minimum & 70 \\
Maximum & 98 \\
Sum & 20703 \\
\hline
\end{tabular}

Merujuk pada tabel tersebut, diperoleh skor rata-rata dari 236 responden sebesar 87,72 yang berarti sebesar $87,72 \%$ dari skor maksimal. Selanjutnya, hasil perolehan data menunjukkan ukuran tendensi sentral yang lain yakni median sebesar 90,00, modus sebesar 90, standar deviasi sebesar 4.818 dan varians sebesar 23.213.

Selanjutnya, distribusi frekuensi hasil belajar PAI peserta didik SMA di Kota Parepare berdasarkan hasil olah data dapat diketahui bahwa skor terendah hasil belajar PAI peserta didik adalah 70 dan skor tertinggi adalah 98. Jika standar kriteria ketuntasan minimal (KKM) pembelajaran yang diterapkan sebagaimana pada penelusuran dokumen di lapangan adalah 75 dan 80 maka terdapat 4 orang responden yang tidak mencapai standar nilai berdasarkan KKM tersebut. Hal ini dapat dilihat pada tabel berikut ini.

Tabel 4. Distribusi Frekuensi Hasil Belajar PAI Peserta Didik 
Hasil Belajar PAI

\begin{tabular}{|c|c|c|}
\hline Kelas Interval & Frekuensi (fi) & Persentase (\%) \\
\hline $70-73$ & 4 & 1.69 \\
\hline $74-77$ & 6 & 2.54 \\
\hline $78-81$ & 20 & 8.47 \\
\hline $82-85$ & 23 & 9.75 \\
\hline $86-89$ & 60 & 25.42 \\
\hline $90-93$ & 114 & 48.31 \\
\hline $94-97$ & 8 & 3.39 \\
\hline $98-100$ & 1 & 0.42 \\
\hline Jumlah & $\mathbf{2 3 6}$ & $\mathbf{1 0 0 . 0 0}$ \\
\hline
\end{tabular}

Jumlah kelas interval pada tabel 6 ditentukan sebanyak 8 kelas dengan panjang kelas $=3$. Frekuensi skor terbanyak berada pada kelas interval 90-93 dengan frekuensi 114 atau setara dengan 48,31\%. Data yang terlihat pada tabel distribusi frekuensi jika dibandingkan dengan harga rata-rata yakni 87,72 menunjukkan bahwa skor hasil belajar PAI peserta didik SMA di Kota Parepare yang berada di bawah kelompok rata-rata sebanyak 53 responden atau setara dengan $22,46 \%$, yang berada pada kelompok skor rata-rata adalah sebanyak 60 responden atau setara dengan $25,42 \%$, dan yang berada pada kelompok di atas rata-rata sebanyak 123 responden, atau setara dengan 52,12\%. Memperhatikan harga persentase tersebut dapat ketahui bahwa kecenderungan perolehan skor hasil belajar PAI peserta didik SMA di Kota Parepare (variable X) berada pada kategori di atas nilai rata-rata.

Selanjutnya, jika penetuan kategori hasil belajar PAI peserta didik didasarkan pada pendapat E. Mulyasa sebagaimana telah dikemukakan pada bagian III, maka dapat diketahui bahwa mayoritas responden (78,39\%) memperoleh skor hasil belajar kategori baik, sisanya 17,37\% kategori amat baik, dan 4,24\% kategori cukup.

Selanjutnya, disajikan pula data distribusi frekuensi dalam bentuk grafik histogram sebagai berikut: 
Gambar 2. Histogram Skor Hasil Belajar PAI Peserta Didik SMA

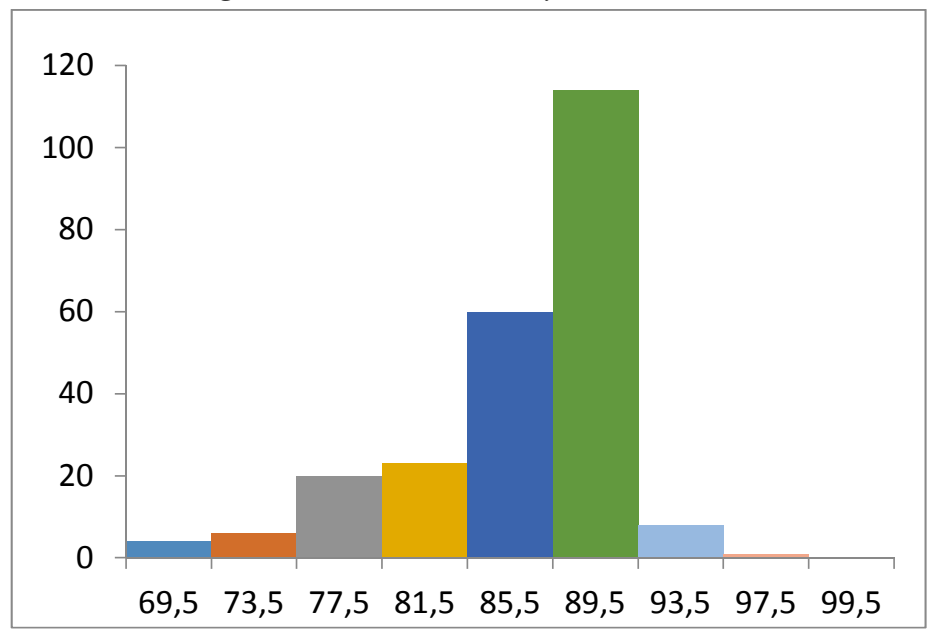

Data pada histogram di atas menggambarkan bahwa peserta didik SMA di Kota Parepare telah memiliki hasil belajar PAI yang baik karena persentase skor terbanyak berada pada kategori baik. Hal ini sesuai pula dengan hasil penelusuran dokumen di lapangan yang menunjukkan adanya hasil belajar PAI mayoritas peserta didik SMA di Kota Parepare berada pada kategori baik. Namun demikian, masih tampak pula dalam penelusuran dokumen dan data terdapat 4 orang responden yang memperoleh skor hasil belajar 70 atau belum mencapai standar kriteria ketuntasan minimal (KKM) yakni 75 dan 80, sehingga masih diperlukan adanya pembelaaran remedial dan upaya lainnya secara berkesinambungan untuk peningkatan kualitas proses dan hasil belajar peserta didik.

\section{Pengujian Persyaratan Analisis}

Persyaratan analisis yang dimaksud adalah persyaratan yang harus dipenuhi agar analisis regresi dapat dilakukan, baik untuk keperluan prediksi maupun untuk keperluan pengujian hipotesis. Analisis data penelitian ini menggunakan teknik analisis korelasi dan regresi sederhan. Namun sebelum teknik analisis statistik tersebut digunakan, data penelitian perlu diuji atau diperiksa persyaratannya. Persyaratan yang harus dipenuhi sebelum melakukan analisis regresi linier sederhana meliputi: uji normalitas. Untuk kepentingan pengujian itu dilakukan uji normalitas sebagai berikut:

\section{Uji Normalitas}

Pengujian normalitas dimaksudkan untuk menguji apakah populasi berdistribusi normal atau tidak. Salah satu uji persyaratan dalam analisis statistika inferensial, khususnya pada uji hubungan adalah data harus berdistribusi normal. Kriteria pengujian berdistribusi normal jika Ho diterima 
dan tidak berdistribusi normal jika Ho ditolak. Di bawah ini output tentang uji normalitas distribusi data galat:

Tabel 5. Uji Normalitas

Tess of Normality

\begin{tabular}{|c|c|c|c|c|c|c|}
\hline & \multicolumn{3}{|c|}{ Kolmogorov-Smirnov ${ }^{\mathrm{a}}$} & \multicolumn{3}{|c|}{ Shapiro-Wilk } \\
\hline & Statistic & $\mathrm{df}$ & Sig. & Statistic & df & Sig. \\
\hline & 040 & 236 & $200^{*}$ & 992 & & 235 \\
\hline Hasil Belajar PAI & 203 & 236 & 000 & 856 & 236 & ,000 \\
\hline
\end{tabular}

*. This is a lower bound of the true significance.

a. Lilliefors Significance Correction

Berdasar pada tabel 5, diketahui bahwa nilai signifikansi 0,200 dan 0,235 > 0,05 sehingga dapat disimpulkan bahwa data yang diuji berdistribusi normal. Lebih lanjut dapat pula dilihat pada tabel berikut ini.

Tabel 6. Uji Normalitas

One-Sample Kolmogorov-Smirnov Tes

\begin{tabular}{|ll|l|}
\hline & & $\begin{array}{l}\text { Unstandardized } \\
\text { Residual }\end{array}$ \\
\hline$N$ & & 236 \\
Normal Parameters, & Mean &, 0000000 \\
& Std. Deviation & 4,68297356 \\
Most Extreme & Absolute &,- 154 \\
Differences & Positive &, 095 \\
Kolmogorov-Smirnov Z & Negative &,- 154 \\
& & 2,359 \\
Asymp. Sig. (2-tailed) & &, 000 \\
& & \\
\hline
\end{tabular}

a. Tes distribution is Normal.

Calculated from data

\section{Uji Linieritas}

Uji linieritas dilakukaan dengan menggunakan uji signifikansi Anova. Adapun kriterianya adalah jika nilai hitung signifikansi pada Deviation from Linierity lebih besar dari 0,05 maka data linier, sebaliknya jika nilai hitung signifikansi pada Deviation from Linierity, lebih kecil dari 0,05 maka data tidak linier. Linieritas Hasil Belajar PAI Peserta Didik (Y) atas Kinerja Guru PAI (X) dapat dilihat pada nilai signifikansi data Hasil Belajar PAI Peserta Didik (Y) atas 
Kinerja Pelaksanaan Guru PAI (X) pada Deviation from Linierity adalah 0,340 sebagaimana ditunjukkan pada tabel berikut ini.

Tabel 7. Uji Linearitas

\begin{tabular}{|c|c|c|c|c|c|c|c|}
\hline & & & $\begin{array}{l}\text { Sum of } \\
\text { Squares }\end{array}$ & $\mathrm{df}$ & $\begin{array}{l}\text { Mean } \\
\text { Square }\end{array}$ & $F$ & Sig. \\
\hline \multirow{6}{*}{$\begin{array}{l}\text { Hasil Belaja } \\
\text { PAI * } \\
\text { Kinerja } \\
\text { Guru PAI }\end{array}$} & & (Combined) & 1524,711 & 62 & 24,592 & 1,082 & 340 \\
\hline & & Linearity & 301,491 & 1 & 301,491 & 13,270 & 000 \\
\hline & Grouns & Deviation & 1223,221 & 61 & 20,053 & 883 & 709 \\
\hline & & from & & & & & \\
\hline & Within Gr & oups & 3930,386 & 173 & 22,719 & & \\
\hline & Total & & 5455,097 & 235 & & & \\
\hline
\end{tabular}

Berdasarkan data pada tabel 9, diperoleh nilai signifikansi Nilai signifikansi $0,340>0,05$, artinya terdapat hubungan yang linier antara variabel hasil Belajar PAI Peserta Didik (Y) dengan variabel kinerja guru PAI (X). Dengan demikian dapat ditafsirkan linier.Nilai signifikansi $0,340<0,05$ menunjukkan bahwa data hasil belajar PAI peserta didik atas kinerja guru PAI ditafsirkan linier. Uji persyaratan regresi terpenuhi.

\section{Pengujian Hipotesis}

Pengujian hipotesis merupakan inti dari permasalahan dalam penelitian yang berisi tentang kebenaran hipotesis berdasarkan data yang diperoleh dari sampel penelitian. Langkah-langkah yang digunakan untuk menjawab hipotesis dalam penelitian ini dengan menggunakan tahapan analisis statistik, yaitu analisis korelasi bivariat dan analisis regresi linear.

\section{Analisis Korelasi}

Analisis korelasi dilakukan untuk mengetahui kuatnya efek hubungan (Correlation effects) antar variabel dalam penelitian yang dinyatakan dalam koefisien korelasi(p). Koefisien korelasi positif paling besar adalah 1 (satu). Apabila hubungam antara dua variabel dalam penelitian ini mempunyai koefisien korelasi $=1$, disebut hubungan yang pasti atau sempurna. Semakin mendekati angka 1 maka menunjukkan hubungan yang semakin kuat. Sebaliknya semakin jauh dari angka1 maka semakin lemah hubungan antar variabel.

Pengolahan data kuantitatif yang digunakan untuk mengetahui pengaruh kinerja guru PAI terhadap hasil belajar PAI peserta didik SMA di Kota Parepare adalah program pengolah data statistik berbasis komputer. 
Pengujian model korelasi dan regresi memerlukan data hasil penelitian yang telah diuji dan memenuhi persyaratan. Data tentang variable kinerja guru PAI (X) dan hasil belajar PAI peserta didik (Y) telah diuji dan telah memenuhi persyaratan. Persyaratan tersebut salah satunya adalah adanya korelasi yang signifikan antara variabel yang terkait.

Hipotesis yang diajukan dalam penelitian ini adalah:

$\mathrm{H}_{a}$ : Ada pengaruh yang signifikan kinerja guru PAI terhadap hasil belajar peserta didik SMA di Kota Parepare. Dalam bentuk statistik sebagai berikut:

$\mathrm{H}_{\mathrm{a}} \mathrm{rxy}=/ 0$

$\mathrm{H}_{\mathrm{o}}: \mathrm{rxy}=0$

Nilai korelasi antar variabel yang diperoleh dari penelitian sebagaimana tampak pada tabel berikut ini.

Tabel 10. Uji Koefisien Korelasi

Correlations

\begin{tabular}{|cl|l|l|}
\hline & & $\begin{array}{l}\text { Kinerja Guru } \\
\text { PAl }\end{array}$ & $\begin{array}{l}\text { Hasil Belajar } \\
\text { PAl }\end{array}$ \\
\hline \multirow{2}{*}{ Kinerja Guru PAI } & Pearson Correlation & 1 & $235^{* *}$ \\
& $\mathrm{~N}$ & 000 \\
& Pearson Correlation & 236 & 236 \\
Hasil Belajar PAI & Sig. (2-tailed) &, 000 & 1 \\
& $\mathrm{~N}$ & 236 & 236 \\
\hline
\end{tabular}

**. Correlation is significant at the 0.01 level (2-tailed).

Berdasarkan hasil perhitungan yang tertera pada tabel 10 diperoleh nilai koefisien korelasi sebesar 0,235. Tampak pula pada hasil perhitungan diperoleh nilai signifikansi sebesar $0,000<\alpha(0,05)$ maka Ho ditolak dan Ha diterima. Artinya terdapat pengaruh yang signifikan kinerja guru PAI terhadap hasil belajar peserta didik SMA di Kota Parepare.

Ringkasan model summary dapat di lihat berikut ini:

Tabel 11. Ringkasan Model Statistik Summary

Model Summary

\begin{tabular}{|l|l|l|l|l|}
\hline Model & $R$ & R Square & $\begin{array}{l}\text { Adjusted R } \\
\text { Square }\end{array}$ & $\begin{array}{l}\text { Std. Error of the } \\
\text { Estimate }\end{array}$ \\
\hline 1 &, $235^{\mathrm{a}}$ & 055 &, 051 & 4,693 \\
\hline
\end{tabular}

a. Predictors: (Constant), Kinerja Guru PAI

Hasil perhitungan data responden dengan menggunakan software SPSS for windows jika diinterpretasikan berdasarkan acuan interpretasi koefisien korelasi sebagaimana yang telah dikemukakan pada bab terdahulu maka terlihat bahwa hasil perhitungan data responden dengan menggunakan aplikasi 
pengolahan statistik diperoleh koefisien korelasi (R) sebesar 0,235. Jika merujuk pada acuan interpretasi koefisien korelasi yang telah dikemukakan oleh Sugiyono maka nilai ini dikategorikan mempunyai hubungan yang memiliki tingkat assosiasi rendah. Arah hubungan yang positif menunjukkan adanya assosiasi yang berbanding lurus. Artinya, peningkatan intensitas kinerja guru PAI akan diikuti oleh peningkatan hasil belajar peserta didik SMA di Kota Parepare.

Koefesien determinasi diperoleh dengan mengkuadratkan koefesien korelasi $\left(R^{2}\right)$ yang menggambarkan seberapa besar kontribusi variabel independen $(X)$ terhadap variabel terikat $(Y)$, karena merupakan kuadrat dari koefesien korelasi maka besaran ini selalu positip dan bernilai antara minimal 0 dan maksimal 1. Dari hasil perhitungan diperoleh koefesien determinasi sebesar 0,55 sebagaimana tampak pada tabel 10, artinya sebesar 55\% variabel independen dapat menjelaskan deviasi dan variabel dependen, sedangkan sisanya $45 \%$ ditentukan oleh variabel lain yang tidak diteliti.

\section{Analisis Regresi}

Penelitian ini menggunakan pula teknik analisis regresi. Analisis regresi bertujuan memprediksi besarnya pangaruh terhadap variabel terikat (dependen) dengan menggunakan variabel bebas (independen) yang sudah diketahui persamaannya. Analisis regresi dilakukan untuk mengetahui bagaimana variabel kriteria (Y) dapat diprediksi melalui variabel prediktor (X). Artinya suatu keadaan naik atau menurunnya variabel bebas.

Analisis regresi yang digunakan dalam penelitian ini adalah regresi sederhana yang didasarkan pada hubungan dua variabel, yakni variabel bebas dan variabel terikat. Variabel bebas dalam penelitian ini adalah kinerja guru PAI dan variabel terikatnya adalah hasil belajar peserta didik.

Persamaan Regresi sederhana menggunakan rumus Ý $=a+b . X$. Berikut ini dikemukakan hasil pengujian SPSS sebagai berikut:

Tabel 12. Koefisien Regresi dan Uji t Koefisien regresi

\section{Coefficients}

\begin{tabular}{|c|c|c|c|c|c|}
\hline \multirow[t]{2}{*}{ Model } & \multicolumn{2}{|c|}{$\begin{array}{l}\text { Unstandardized } \\
\text { Coefficients }\end{array}$} & $\begin{array}{l}\text { Standardized } \\
\text { Coefficients }\end{array}$ & $\mathrm{t}$ & Sig. \\
\hline & $B$ & Std. Error & Beta & & \\
\hline (Constant) & 101,124 & 3,635 & & 27,823 &, 000 \\
\hline $\begin{array}{l}1 \text { Kinerja Guru } \\
\text { PAI }\end{array}$ & ,079 & ,021 & 235 & 3,700 &, 000 \\
\hline
\end{tabular}

Dependent Variable: Hasil Belajar PAI 
Tabel koefisien regresi tersebut diperoleh harga komponen $\mathrm{a}=101,124$. Dan harga komponen $b=0,079$. Harga a merupakan besarnya harga $Y$ apabila harga $X=0$. Sedangkan harga $b$ adalah nilai koefisien regresi $Y$ atas $X$.

Berdasarkan hasil perhitungan regresi sederhana maka diperoleh harga persamaan regresi $\hat{Y}=101,124+0,079$. Hasil pengujian ini dapat diprediksi apabila kinerja guru PAI sebagai variabel prediktor $X$ ditingkatkan maka akan terjadi peningkatan yang signifikan pada variabel $Y$ sebagai dampak dari tingkat keterhubungan (correlation effects) variabel $X$ terhadap $Y$. Data yang tercantum pada tabel 12 menggambarkan prediksi perolehan $\mathrm{Y}$ bertambah sebesar 0,079 X.

Selanjutnya, kriteria signifikansi regresi hubungan $X$ dengan $Y$ dikatakan signifikan apabila nilai $\mathrm{p}$ value sig $\leq 0,05$. Pada tabel 12 tampak pada kolom sig. 0,00 lebih kecil dari 0,05 sehingga dapat disimpulkan bahwa regresi hubungan kinerja guru $(X)$ dan hasil belajar (Y) signifikan. Selain uji regresi, dilakukan pula uji $\mathrm{F}$ yang bertujuan untuk melihat arah nyata pada taraf kepercayaan $95 \%$. Kriteria probabilitas harga $\mathrm{F}$ adalah $\mathrm{F}_{\text {hitung }} \leq$ dari $\mathrm{F}_{\text {tabel }}$ dengan derajat kebebasan tertentu. Berikut ini dikemukakan hasil uji F model ANOVA.

Tabel 13. Hasil Uji F Anova

ANOVA $^{a}$

\begin{tabular}{|l|l|l|l|l|l|}
\hline Model & Sum of Squares & df & Mean Square & F & Sig. \\
\hline \multirow{2}{*}{$\begin{array}{l}\text { Regression } \\
1\end{array}$ Residual } & 301,491 & 1 & 301,491 & 13,689 &, $000^{\mathrm{b}}$ \\
\multicolumn{1}{|c|}{ Total } & 5153,607 & 234 & 22,024 & & \\
\hline
\end{tabular}

a. Dependent Variable: Hasil Belajar PAI

b. Predictors: (Constant), Kinerja Guru PAI

Hasil pengolahan data dengan menggunakan perangkat lunak komputer diperoleh data sebagaimana pada Tabel 13 Uji F pada struktur hubungan dengan nilai Fhitung sebesar 13,689 $>3,89$ dengan signifikansi $0,000<\alpha=0,05$. Ini menunjukkan bahwa model regresi yang diperoleh signifikan sehingga dapat dilanjutkan ke uji t.

Dengan kaidah pengujian $t$ hitung lebih besar dari $t$ tabel, maka Ho ditolak, artinya terdapat pengaruh yang signifikan, dan jika $t$ hitung lebih kecil dari $t$ tabel maka Ho diterima, artinya tidak terdapat hubungan sifnifikan. Perhitungan nilai t dengan bantuan aplikasi statistik disajikan dalam tabel 12 .

Data pada tabel 12 menunjukkan nilai t hitung yang diperoleh lebih besar dari t tabel sebesar 27,823 > 1,987. Ini berarti Ho ditolak dan Ha diterima. Artinya terdapat pengaruh yang signifikan kinerja guru PAI terhadap hasil belajar peserta didik SMA di Kota Parepare. 
Sebagaimana telah dikemukakan pada bagian pendahuluan bahwa penelitian ini difokuskan pada bagaimana pengaruh kinerja guru PAI terhadap hasil belajar peserta didik SMA di Kota Parepare. Kemudia penelitian ini juga mengangkat masalah: Bagaimana tingkat kinerja guru Pendidikan Agama Islam SMA di Kota Parepare?, Bagimana hasil belajar Pendidikan Agama Islam peserta didik SMA di Kota Parepare?, dan Apakah ada pengaruh kinerja guru PAI terhadap hasil belajar peserta didik SMA di Kota Parepare?.

Penelitian ini juga berangkat dari sebuah hipotesis yaitu ada pengaruh kinerja guru PAI terhadap hasil belajar peserta didik SMA di Kota Parepare. Dengan demikian uraian yang disajikan berikut ini berusaha untuk menjawab masalah pokok penelitian dan membuktikan hipotesis, yang dihubungkan dengan tinjauan teoretis yang telah dikemukakan pada tinjauan teoretis atau tinjauan pustaka.

\section{Tingkat Kinerja Guru PAI SMA di Kota Parepare}

Pengukuran tingkat kinerja guru dalam penelitian ini secara khusus didasarkan pada PP. No. 74 tahun 2008 tentang guru Bab IV mengenai beban kerja guru pasal 52 yakni perencanaan pembelajaran, pelaksanaan pembelajaran, dan menilai hasil belajar peserta didik, dengan beberapa indikator yakni :persiapan dan perencanaan pembelajaran, penerapan teori dan prinsip belajar yang mendidik, bekerja dan komunikasi dengan peserta didik, pendayagunaan media pembelajaran, melibatkan peserta didik dalam berbagai pengalaman belajar, kepemimpinan yang aktif dari guru, memahami dan mengembangkan potensi peserta didik, penilaian dan evaluasi. Hal ini sejalan dengan tinjauan teoretis yang telah dikemukakan pada bagian terdahulu yakni isi UndangUndang RI Nomor 14 tahun 2005 tentang guru dan dosen khususnya kompetensi pedagogik guru, dan pendapat Piet A. Sahertian dalam Barnawi tentang standar kinerja guru yang berhubungan dengan kualitas guru dalam menjalankan tugasnya.

Hasil olah data statistik deskriptifmenunjukkan bahwa skor kinerja guru PAI SMA di Kota Parepare yang berada di bawah kelompok rata-rata sebanyak 65 responden atau setara dengan $27.54 \%$, yang berada pada kelompok skor ratarata adalah sebanyak 58 responden atau setara dengan $24.58 \%$, dan yang berada pada kelompok skor di atas harga rata-rata sebanyak 113 responden, atau setara dengan $47.88 \%$. Hal ini menunjukkan bahwa kecenderungan perolehan skor kinerja Guru PAI SMA di Kota Parepare (variable X) dapat dikategorikan baik.

Selanjutnya, berdasarkan hasil analisis statistik terhadap data yang diperoleh dari responden ditemukan tingkat kinerja guru PAI dengan membagi skor perolehan dengan skor kriterium yakni $40.050: 50.740=0,7893$ atau $78,93 \%$ 
dari kriterium yang ditetapkan sehingga dapat disimpulkan bahwa tingkat kinerja guru PAI SMA di Kota Parepare termasuk kategori baik. Hal ini sejalan dengan hasil penelusuran dokumen pengisian penilaian kinerja guru (PKG) yang telah disahkan oleh masing-masing Kepala SMA untuk guru mata pelajaran PAI di lokasi penelitian yang menunjukkan hasil penilaian kinerja guru PAI pada SMA sampel penelitian dengan skor rata-rata 83,23 atau berada pada kategori baik pula.

Temuan dalam penelitian ini, yang didasarkan pada persepsi peserta didik tentang kinerja guru PAI SMA di Kota Parepare baik dalam membuat perencanaan pembelajaran maupun dalam pelaksanaan pembelajaran dan penilaian hasil belajar peserta didik, hampir sama dengan hasil penilaian kinerja guru (PKG) yang dilakukan oleh pengawas PAI. Apabila temuan ini dibandingkan dengan hasil penelusuran dokumen yang berkenaan dengan penilaian kinerja guru yang dilakukan oleh pengawas PAI yang telah disahkan oleh kepala SMA masing-masing maka hasil PKG yang terdokumentasi tersebut lebih besar yakni 83,23 dibanding persepsi responden yakni 78,93 atau terdapat selisih 4,3, namun demikian kedua skor tersebut barada pada kategori yang sama yakni kategori baik. Hal ini berarti guru PAI SMA di Kota Parepare telah memiliki kinerja yang baik, namun demikian tentunya masih perlu ditingkatkan menjadi lebih baik atau amat baik.

\section{Analisis Hasil Belajar Peserta Didik SMA di Kota Parepare}

Hasil belajar peserta didik sebagaimana yang terlihat pada daftar distribusi frekuensi yang telah dikemukakan sebelumnya pada tablel 6 jika di rujuk pada pedoman pengkategorian sebagaimana yang telah dikemukakan pada Bab III, maka dapat diketahui bahwa hasil belajar PAI peserta didik cenderung berada pada kategori baik, dengan skor rata-rata sebesar 87,72. Perolehan skor rata-rata tersebut berada pada kelas interval 86-89. Terdapat 123 responden atau setara dengan 52,12\% memperoleh skor hasil belajar berada di atas kelompok rata-rata, terdapat 60 responden atau setara dengan 25,42\% memperoleh skor hasil belajar berada pada kelompok rata-rata, dan sisanya 53 responden atau setara dengan $22,46 \%$ di bawah harga rata-rata. Nilai tersebut menunjukkan bahwa hasil belajar peserta didik SMA di Kota Parepare cenderung baik.

Selanjutnya terlihat bahwa hampir semua peserta didik yang menjadi sampel dalam penelitian ini telah memperoleh nilai tuntas berdasarkan standar Kriteria Ketuntasan Minimal (KKM) yang telah ditetapkan oleh guru PAI yakni 75 dan 80, meskipun ada di antara mereka mencapai standar kriteria ketuntasan minimal setelah mengikuti pembelajaran remedial. Terdapat 4 responden yang 
tidak mencapai standar KKM yang telah ditetapkan pada sekolah yang bersangkutan. Hal ini menunukkan bahwa telah ada berbagai upaya guru PAI meningkatkan hasil belajar peserta didik dan capaian hasil belajar ini perlu dipertahankan bahkan ditingkatkan, antara lain melalui upaya peningkatan kinerja guru PAI.

\section{Pengaruh Kinerja Guru terhadap Hasil Belajar Peserta Didik}

Berdasarkan hasil pengujian hipotesis diperoleh nilai koefisien korelasi sebesar 0,235. Tampak pada hasil perhitungan diperoleh nilai signifikansi sebesar $0,000<\alpha(0,05)$ maka Ho ditolak dan Ha diterima. Artinya, terdapat pengaruh yang signifikan kinerja guru PAI terhadap hasil belajar peserta didik SMA di Kota Parepare.

Hasil perhitungan pegujian hipotesis menunjukkan terdapat pengaruh langsung antara variabel independen $(X)$ dengan variable dependen $(Y)$ serta positif dan signifikan. Pengaruh langsung tersebut yaitu kinerja guru PAI berpengaruh terhadap hasil belajar PAI peserta didik SMA di Kota Parepare.

Hasi penelitan ini telah memberikan bukti empiris bahwa variable independen yaitu kinerja guru PAI (X) turut menentukan hasil belajar PAI sebagai variabel dependen (Y). Selanjutnya untuk mengetahui bagaimana pengaruh antara variabel independen dengan variabel dependen, dapat dijelaskan sebagai berikut:

Pertama: Kinerja guru PAI ( $\left.\mathrm{r}_{\mathrm{xy}}\right)$ berkorelasi dengan hasil belajar Pendidikan Agama Islam (PAI) peserta didik sebesar 23,5\% . Artinya hasil belajar PAI peserta didik dipengaruhi oleh kinerja guru pada saat proses pembelajaran di kelas.

Kedua: Koefisien determinan atau kontribusi kinerja guru PAI terhadap hasil belajar PAI ( $R_{\text {square }}=\mathrm{R}^{2}$ ) adalah 0,55 yang berarti bahwa $55 \%$ variasi hasil belajar PAI dapat dijelaskan oleh kinerja guru PAI. Artinya $45 \%$ hasil belajar PAI ditentukan oleh faktor lain yang tidak diamati dalam penelitian ini.

Berdasarkan hasil perhitungan analisis korelasi menunjukkan bahwa kinerja guru memberikan pengaruh positif pada berbagai pelaksanaan fungsi dan tugas seorang guru. Temuan ini sejalan dengan tinjauan teori yang mengungkapkan bahwa kinerja guru merupakan faktor yang turut mempengaruhi prestasi peserta didik. Sebagaimana yang telah dikemukakan pada kajian teoretis menurut T. R. Mitchel dan Ivancevich dalam Rusman bahwa, "Salah satu ukuran standar kinerja adalah quality of works, hal ini diperjelas oleh Ivancevich bahwa ukuran kualitas kinerja guru dapat dilihat dari produktivitas pendidikan yang telah dicapai menyangkut output peserta didik yang 
dihasilkan". Tinggi rendahnya kualitas output peserta didik yang dihasilkan antara lain ditentukan oleh tinggi rendahnya kinerja guru.

Berdasar pada uraian yang telah dikemukakan di atas dapat ditarik kesimpulan bahwa dalam rangka meningkatkan hasil belajar PAI peserta didik, kinerja guru PAI dalam pelaksanaan tugasnya tidak dapat diabaikan, termasuk dalam hal perencanaan pembelajaran, pelaksanaan proses pembelajaran, dan penilaian hasil belajar peserta didik. Dengan demikian temuan yang dapat diperoleh mengungkapkan bahwa kinerja guru PAI mempunyai pengaruh yang signifikan terhadap hasil belajar PAI peserta didik SMA di Kota Parepare. Hal ini berarti bila kinerja guru PAI ditingkatkan, maka hasil belajar peserta didik akan meningkat pula.

\section{SIMPULAN}

Pelaksanaan penelitian ini berusaha mengkaji tentang pengaruh kinerja guru PAI terhadap hasil belajar peserta didik pada SMA di Kota Parepare, yang hasilnya dapat disimpulkan sebagai berikut:

1.Kinerja guru PAI SMA di Kota Parepare berada pada kategori baik, denganskor capaian tingkat kinerja sebesar 78,93\% dari kriterium yang ditetapkan. Terdapat $27.54 \%$ guru memperoleh skor kinerja di bawah kelompok rata-rata, $24.58 \%$ berada pada kelompok skor rata-rata, dan $47.88 \%$ berada pada kelompok skor di atas harga rata-rata.

2. Hasil belajar PAI peserta didik cenderung berada pada kategori baik dengan skor rata-rata sebesar 87,72. Mayoritas responden yakni 78,39\% memperoleh skor hasil belajar kategori baik, sisanya 17,37\% kategori amat baik, dan $4,24 \%$ kategori cukup.

3. Terdapat pengaruh yang signifikan kinerja guru PAI terhadap hasil belajar peserta didik SMA di Kota Parepare dengan koefisien korelasi sebesar $23,5 \%$ dan nilai signifikansi sebesar $0,000 \leq \alpha(0,05)$. Kontribusi kinerja guru PAI terhadap hasil belajar PAI adalah 0,55 yang berarti bahwa 55\% variasi hasil belajar PAI dapat dijelaskan oleh kinerja guru PAI dan $45 \%$ ditentukan oleh faktor lain yang tidak diamati dalam penelitian ini. Artinya, peningkatan intensitas kinerja guru PAI akan diikuti oleh peningkatan hasil belajar PAI peserta didik SMA di Kota Parepare. 


\section{REFERENCE}

(1) Danim, Sudarman, Inovasi Pendidikan dalam Upaya Peningkatan Profesionalisme Tenaga Kependidikan, Bandung: Pustaka Setia, 2009

(2) Dinas Pendidikan Nasional Kota Parepare, Agenda Tahunan Akademik SMA Negeri dan SwastaKota Parepare, tahun 2013

(3) Munandar, Krerativitas dan Keberbakatan Strategi Mewujudkan Potensi Kreatif Guru, Jakarta: PT Gramedia Pustaka Utama, 2000

(4) Republik Indonesia, Undang-undang SISDIKNAS (Sistem Pendidikan Nasional) (UU RI No. 20 Th. 2003) Dilengkapi dengan PP RI No. 48 dan 47 Th. 2008, PERMENDIKNAS No. 49, 19, 15, 13, Th. 2007 , Jakarta: Sinar Grafika, 2013

(5) Singarimbun, Masri dan Efendi, Sofyan, Metode Penelitian Survay, Jakarta: LP3ES, 2000

(6) Sugiyono, Metode Penelitian Administrasi, Bandung: Alfabeta, 2007

(7) Sugiyono, Metode Penelitian Pendidikan, Pendekatan Kuantitatif, Kualitatif, dan R\&D, Cet. Ke-18, Bandung: Alfabeta, 2013

(8) Sumadi, Penyakit Guru Masa Kini, Yogyakarta : Candra, 2012

(9) Sujana N, Penilaian Hasil Proses Belajar Mengajar. Bandung: PT Remaja Rosdakarya, 2010

(10) Supardi, Kinerja Guru, Cet. Ke-1, Jakarta: Rajawali Pers, 2013.

(11) Suprihatiningrum, Strategi Pembelajaran, Teori dan aplikasi, cet. I, Jakarta: Ar- Ruzz Media, 2013.

(12) Suprihatiningrum, Jamil, Guru professional, Pedoman kinerja, kualifikasi, dan kompetensi guru,Cet. I, Jakarta: Ar-Ruzz Media, 2013

(13) ............, Penilaian Hasil Belajar Mengajar, Cet. XVI, Bandung, Rosdakarya, 2011.

(14) Sugiyono, Statistika Penelitian, Bandung: Alfabeta, 2009.

(15) Sukardi, Evaluasi Pendidikan, Prinsip dan Operasionalnya, Cet. III, Jakarta: Bumi Aksara, 2009.

(16) Sukmadinata, Nana Syaodih, et.al, Pengendalian Mutu Pendidikan Sekolah Menengah, (Konsep, Prinsip, dan Instrumen). Cet. II, Bandung, PT. Refika Aditama, 2008

(17) ---------, Inovasi Pendidikan, Cet. IV, Bandung, Alfabeta, 2011.

(18) Sumadi, Penyakit Guru Masa Kini, Yogyakarta: Candra, 2012.

(19) Slameto, Belajar dan Faktor-faktor yang <Mempengaruhinya, Edisi Revisi, Cet. V, Jakarta, Rineka Cipta, 2010.

(20) Tafsiran TAP MPR Nomor 2/IV/ MPR/1999, tentang Garis-Garis Besar Haluan Negara.

(21) Thoha, M. Chabib. Teknik Evaluasi Pendidikan. Cet. V; Jakarta: PT. RajaGrafindo Persada, 2003.

(22) Thorndike, Robert L dan Elisabeth P. Hagen Measurement and Aevaluation in Psychology and Education Fourth Edition. New York: John Wiley and Sons, t.th. 
(23) Tafsir, Ahmad, Ilmu Pendidikan dalam Presfektif Islam, Cet. III, Bandung, PT. Remaja Rosdakarya, 2000.

(24) Tim Penyusun Kamus Pusat Pembinaan dan Pengembangan Bahasa Departemen Pendidikan dan Kebudayaan, Kamus Besar Bahasa Indonesia, edisi II;Cet. I; Jakarta: Balai Pustaka, 1991.

(25) Tohirin, Psikologi Pembelajaran Pendidikan Agama Islam: Berbasis Integrasi dan Kompetensi, Jakarta: Raja Grafindo, 2006.

(26) Kemdiknas, Pembinaan dan pengembangan Profesi Guru, Pedoman Pelaksanaan Penilaian Kinerja Guru (PK Guru).

(27) Trianto, Mendesain Pembelajaran Kontestual (Contextual Teaching And Learning) di Kelas, Cet. I, Jakarta, Cerdas Pustaka Publisher, 2008. 